\title{
Isolation and Absolute Configuration Determination of Aliphatic Sulfates as the Daphnia Kairomones Inducing Morphological Defense of a Phytoplankton
}

\author{
Ko Yasumoto, ${ }^{a}$ Akinori Nishigami, ${ }^{a}$ Fumie Kasai, ${ }^{b}$ Takenori Kusumi, ${ }^{a}$ and Takashi OoI ${ }^{*}, a$ \\ ${ }^{a}$ Graduate School of Pharmaceutical Sciences, Tokushima University; Tokushima, Tokushima 770-8505, Japan: and \\ ${ }^{b}$ National Institute for Environmental Studies; Onogawa, Tsukuba 305-8506, Japan. \\ Received October 20, 2005; accepted November 1, 2005; published online November 8, 2005
}

\begin{abstract}
2,6-Dimethylheptyl sulfate (1) and 6-methyloctyl sulfate (3) were isolated from Daphnia pulex as the Daphnia kairomones that induced morphological defense of a freshwater phytoplankton Scenedesmus gutwinskii var. heterospina (NIES-802). The absolute stereochemistry at $\mathrm{C} 2$ of 1 was determined by ${ }^{1} \mathrm{H}-\mathrm{NMR}$ analysis of the $(R)-$ MTPA ester of alcohol 2. The absolute configuration at $\mathrm{C} 6$ of 3 was determined by Ohrui's method applied to alcohol 4.
\end{abstract}

Key words Daphnia kairomone; Scenedesmus; aliphatic sulfate; absolute configuration

In aquatic environments, phytoplankton is the bottom creature playing an important role in the food chain. It has been soundly believed that phytoplankton is docile and never resists against its fate. Recently, it became clear that many phytoplankton resist their predators using various strategies. Scenedesmus, a unicellular fresh-water phytoplankton, resists its grazer by changing its morphology. Addition of filtered medium of Daphnia, a grazer of the plankton, to unicellular Scenedesmus subspicatus achieves morphological change into 2, 4, and 8 colonies within a few days. Such a change of morphology increases resistance of the colonies against grazer. ${ }^{1)}$ This metamorphosis was supposed to be a self-defense mechanism acquired by the phytoplankton and triggered by a kairomone secreted from Daphnia. ${ }^{1)}$

Recently, we reported identification of the Daphnia kairomones that cause the morphological change in a unicellular green alga Scenedesmus gutwinskii var. heterospina (NIES-802) at $10^{-1}-10^{3} \mathrm{ng} / \mathrm{ml}$ concentrations. ${ }^{2)}$

Here we report isolation and absolute configuration determination of new aliphatic sulfates $\mathbf{1}$ and $\mathbf{3}$ as the Daphnia kairomones. The absolute stereochemistrys at $\mathrm{C} 2$ of $\mathbf{1}$ and $\mathrm{C} 6$ of 3 were determined by ${ }^{1} \mathrm{H}-\mathrm{NMR}$ analysis of the $(R)$ MTPA ester of alcohol 2 and Ohrui's method applied to alcohol 4, respectively.

Frozen Daphnia (10 kg; Aso Tropical Fish Co. Ltd., Osaka) was soaked with methanol $(201 \times 3)$, and the methanol solution was evaporated, the residue being treated with water (91). The mixture was successively extracted with hexane, dichloromethane, and butanol, and the most active butanol extract was separated by HPLC monitoring the activity $^{2)}$ to afford $\mathbf{1}(9 \mathrm{mg}$ ) and $\mathbf{3}$ (5 mg) (Fig. 1).

The molecular formulae of $\mathbf{1}$ and $\mathbf{3}$ were established as $\mathrm{C}_{9} \mathrm{H}_{19} \mathrm{O}_{4} \mathrm{~S}$ on the basis of HR-FAB-MS. The presence of a sulfate group was suggested by a fragment ion peak at $\mathrm{m} / \mathrm{z} 97$

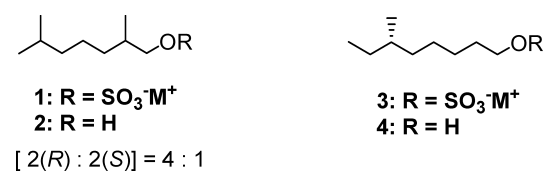

Fig. 1. The Structure of Daphnia Kairomones $\mathbf{1}$ and $\mathbf{3}$

The countercations were not identified and expressed as $\mathrm{M}^{+}$.
$\left(\mathrm{HSO}_{4}^{-}\right)$in the negative ion FAB-MS of $\mathbf{1}$ and 3. The ${ }^{1} \mathrm{H}-$ NMR spectrum of 1 exhibited three doublet methyls at $\delta$ $0.98(3 \mathrm{H}, \mathrm{d}, J=6.7 \mathrm{~Hz}, \mathrm{Me}-2)$ and $0.91(6 \mathrm{H}, \mathrm{d}, J=6.6 \mathrm{~Hz}, \mathrm{H}-$ 7 , Me-6), two protons of a methylene bearing a sulfate group at $\delta 3.90(1 \mathrm{H}$, dd, $J=9.4,5.8 \mathrm{~Hz}, \mathrm{H}-1)$ and $3.81(1 \mathrm{H}$, dd, $J=9.4,6.7 \mathrm{~Hz}, \mathrm{H}-1)$ and eight methine/methylene protons at $\delta 1.12-1.88$. Interpretation of the ${ }^{1} \mathrm{H}-{ }^{1} \mathrm{H}$ COSY spectrum of $\mathbf{1}$ led to a gross structure as 2,6-dimethylheptyl sulfate. ${ }^{3-5)}$

The absolute stereochemistry at C-2 of $\mathbf{1}$ was determined by the ${ }^{1} \mathrm{H}$-NMR analysis of $(R)$ - $\alpha$-methoxy- $\alpha$-(trifluoromethy)phenylacetic acid (MTPA) ester of 2, a hydrolysis product. It has been established that, ${ }^{6}$ in the ${ }^{1} \mathrm{H}$-NMR of an MTPA ester of a 2(S)-methyl aliphatic alcohol, the chemical shift difference of the methylene protons at $\mathrm{C} 1$ (appearing as an ABX pattern) is larger in the (S)-MTPA ester than in the $(R)$-MTPA ester. The reverse holds true for a $2(R)$-methyl alcohol.

Sulfate 1 was hydrolyzed by heating with $3 \mathrm{M} \mathrm{HCl}$, and the resulting alcohol 2 was treated with an excess of $(+)-(S)-\alpha-$ methoxy- $\alpha$-(trifluoromethy)phenylacetyl chloride (MTPA$\mathrm{Cl})$ in pyridine- $d_{5}$ to yield the (R)-MTPA ester (5). In its ${ }^{1} \mathrm{H}-$ NMR spectrum, two sets of the AB signals of ABX patterns due to the methylene protons at $\mathrm{C} 1$ appear at $\delta 4.33(1 \mathrm{H}$, dd, $J=10.7,5.8 \mathrm{~Hz})$ and $4.16(1 \mathrm{H}, \mathrm{dd}, J=10.7,6.6 \mathrm{~Hz})$ [major: $2(R)-5(=10)]$, and at $4.26(1 \mathrm{H}, \mathrm{dd}, J=10.7,6.1 \mathrm{~Hz})$ and 4.23 $(1 \mathrm{H}, \mathrm{dd}, J=10.7,5.9 \mathrm{~Hz}$ ) [minor: 2(S)-5 (=9)] (Fig. 2). These ${ }^{1} \mathrm{H}-\mathrm{NMR}$ data for the MTPA esters (5) indicated that natural 1 was a $4: 1$ mixture of $2(R)$ and $2(S)$ enantiomers (Fig. 2).

We were interested which enantiomar had stronger activity. Therefore, we synthesized 2(R)- and 2(S)-1 by the reactions shown in Chart 1 . The olefin of aldehyde 6 was hydrogenated over Pd-C catalyst, followed by reduction of the subsequent aldehyde to primary alcohol with $\mathrm{LiAlH}_{4}$. The racemic alcohol $\left(\mathrm{rac}-2^{7}\right)$ was esterified with $(S)$-methoxy-(1naphthyl) acetic acid ((S)-1NMA). ${ }^{8,9)}$ The $(S)$-1NMA esters were separated to 7 and $\mathbf{8}$ by recycling HPLC. Hydrolysis of $\mathbf{7}$ and $\mathbf{8}$ afforded $2(S)$ - and $2(R)-2,{ }^{7)}$ respectively, the absolute configuration of which was confirmed by the MTPA method: $(R)$-MTPA ester $(9)$ of $2(S)$-2 shows an overlapped AB pattern of $\mathrm{H}_{2}-1$, while $(R)$-MTPA ester $(\mathbf{1 0})$ of $2(R)$-2 shows a well-separated $\mathrm{AB}$ pattern (Experimental). Interestingly, the 

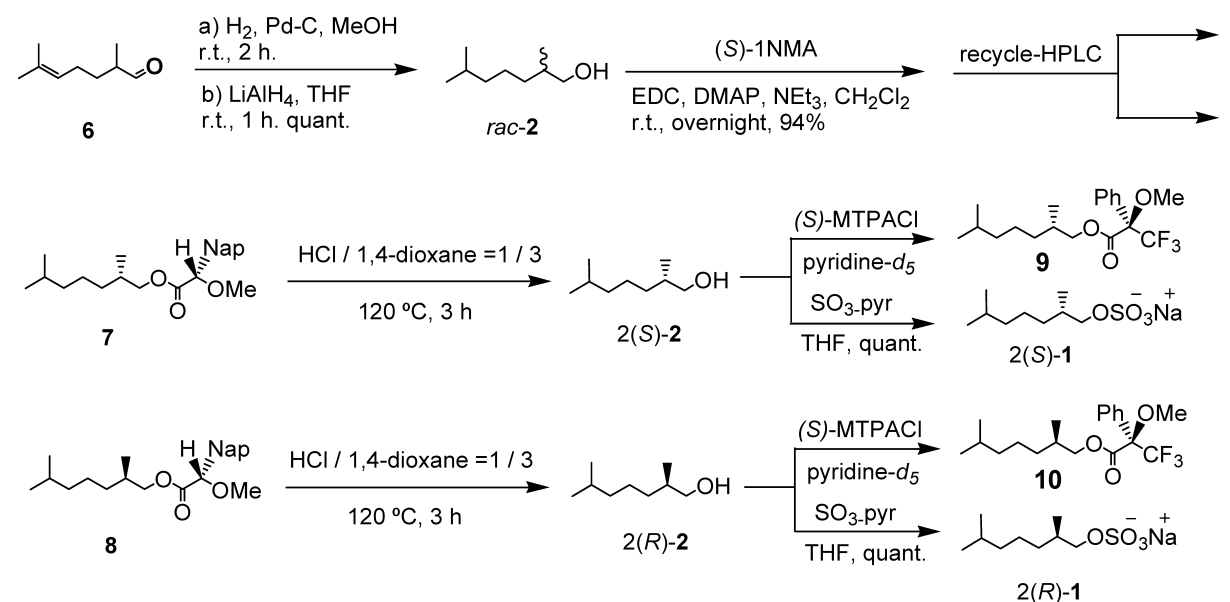

Chart 1. Synthesis of $(R)$-MTPA Esters 9 and 10, and Sulfates $2(S)-\mathbf{1}$ and $2(R)-\mathbf{1}$

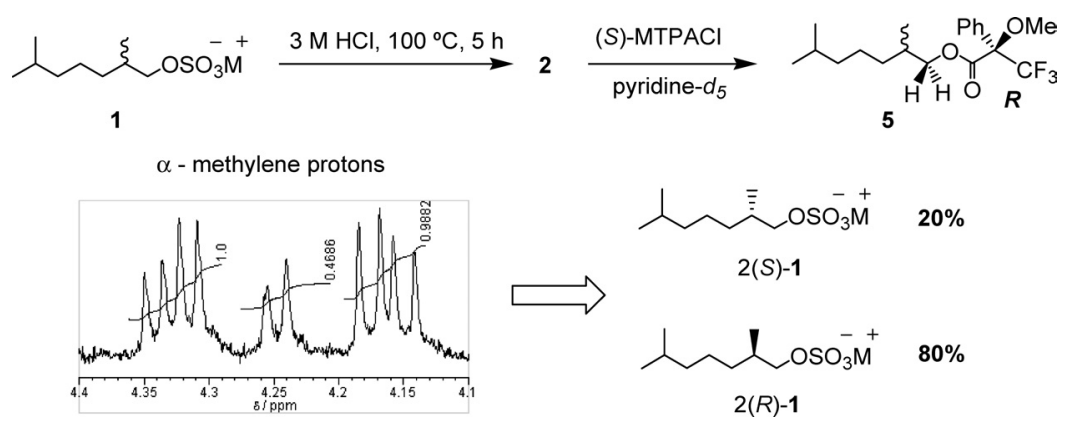

Fig. 2. Determination of the Absolute Configuration of $\mathbf{1}$

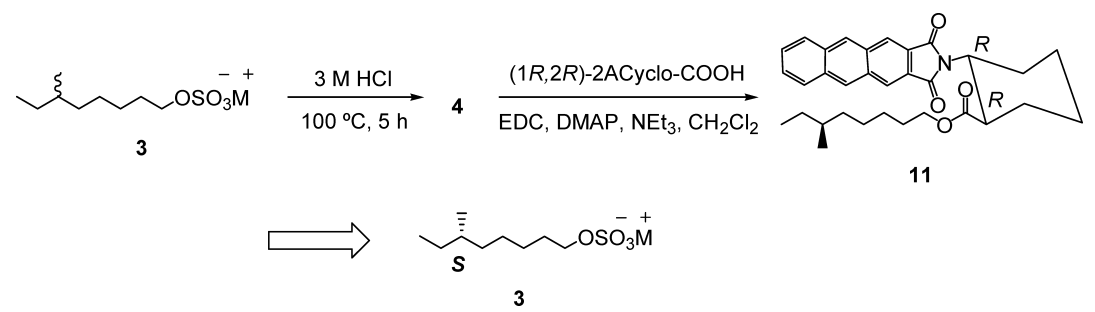

Fig. 3. Determination of the Absolute Configuration of $\mathbf{3}$

(S)-1NMA derivatives 7 and $\mathbf{8}$ show the ${ }^{1} \mathrm{H}-\mathrm{NMR}$ patterns of $\mathrm{H}_{2}-1$ opposite to those of the MTPA esters: the $(S)-1 \mathrm{NMA}$ ester of 2(S)-2 exhibits a narrow AB pattern of $\mathrm{H}_{2}-1$ and $(S)$ MTPA ester of 2(S)-2 is a well separated pattern (Experimental). $2(S)$ - and $2(R)-2$ were sulfated, giving $2(S)-\mathbf{1}$ and $2(R)-\mathbf{2}$, respectively. Then, we examined that the morphological change activity of the compounds. But, there were no difference in the activity between $2(R)$ - and $2(S)$-sulfates.

The ${ }^{1} \mathrm{H}-\mathrm{NMR}$ spectrum of $\mathbf{3}$ reveals two methyl groups at $\delta 0.92(3 \mathrm{H}, \mathrm{t}, J=7.8 \mathrm{~Hz}, \mathrm{H}-8), 0.91(3 \mathrm{H}, \mathrm{d}, J=7.4 \mathrm{~Hz}$, Me-6), methylene protons bearing a sulfate group at $\delta 4.03$ $(2 \mathrm{H}, \mathrm{t}, J=6.6 \mathrm{~Hz}, \mathrm{H}-1)$, and 11 methine/methylene protons at $\delta$ 1.73-1.10. The ${ }^{1} \mathrm{H}-{ }^{1} \mathrm{H}$ COSY, HSQC and HMBC NMR spectra of 3 were consistent with the structure of 6methyloctyl sulfate. To the best of our knowledge, 3 is a new compound. The absolute stereochemistry at C-6 of $\mathbf{3}$ was determined by the ${ }^{1} \mathrm{H}-\mathrm{NMR}$ analysis of a $(1 R, 2 R)-2$ (2,3-anthracenedicarboximido)cyclohexanecarboxylic acid $\left((1 R, 2 R)-2\right.$ ACyclo-COOH, Ohrui reagent) ester. ${ }^{10)}$
The alcohol derivative $\mathbf{4}$, obtained by hydrolysis of $\mathbf{3}$ with $3 \mathrm{M} \mathrm{HCl}$, was condensed with $(1 R, 2 R)-2 \mathrm{ACyclo}-\mathrm{COOH}$ to yield ester 11. The methyl proton signals of the ester appeared at $\delta 0.70(3 \mathrm{H}, \mathrm{t}, J=7.2 \mathrm{~Hz}, \mathrm{H}-8)$ and $0.62(3 \mathrm{H}, \mathrm{d}$, $J=6.6 \mathrm{~Hz}, \mathrm{Me}-6)$. These chemical shifts are the same with those of the methyl protons of $(1 R, 2 R)-2 \mathrm{ACyclo}-\mathrm{COOH}$ ester of $6(S)$-methyloctan-1-ol, ${ }^{10)}$ leading to the $6(S)$-configuration of 3. This experiment also indicated that natural $6(S)-3$ was free from its antipode.

\section{Experimental}

High-resolution MS were recorded on a JEOL JMS-SX102A spectrometer. ${ }^{1} \mathrm{H}$ - and ${ }^{13} \mathrm{C}$-NMR spectra were obtained on a Bruker Avance-400 $\left({ }^{1} \mathrm{H}\right.$ and ${ }^{13} \mathrm{C}$ at 400 and $100 \mathrm{MHz}$, respectively). Assignments of the proton and carbon signals were established by COSY, HSQC and HMBC spectra. Optical rotations were determined on a JASCO DIP-370 polarimeter.

Bioassay Each $200 \mathrm{ml}$ of C medium of S. gutwinskii $\left(5.0 \times 10^{2}\right.$ cells $\left./ \mathrm{ml}\right)$ is delivered into the central $30-50$ wells of 96 -well polystyrene tissue culture plate (CELLSTAR, Greiner Bio-one Co., Ltd) containing the test samples $(1000-0.01 \mathrm{ng} / \mathrm{ml})$, and the outer wells are filled with distilled water to avoid dehydration of the system. The plate is covered with a plastic lid, and 
incubated at $20^{\circ} \mathrm{C}$ (12 light/12 dark) for $10 \mathrm{~d}$. A drop of the medium is placed on a Thoma's hemacytometer, and the numbers of 1-, 2-, 4-, and 8cell types were counted under a microscope $(\times 200)$.

Extraction and Isolation Frozen Daphnia (10 kg; Aso Tropical Fish Co. Ltd., Osaka) was soaked with methanol $(201 \times 3)$, and the methanol solution was evaporated, the residue being treated with water (91). The mixture was successively extracted with hexane (91), dichloromethane (91), and butanol (91), and the most active butanol extract ( $18 \mathrm{~g}$ ) was chromatographed on a Cosmosil $75 \mathrm{C}_{18}$-OPN (25 g), eluting with $\mathrm{MeOH}-\mathrm{H}_{2} \mathrm{O}$ in a gradient manner $(1: 1 \rightarrow 10: 0)$. The active fractions were further purified by HPLC (CAPCELLPAK $\mathrm{C}_{18}$ column, $5 \mu \mathrm{m}, 10 \times 250 \mathrm{~mm}, \mathrm{MeCN}-\mathrm{H}_{2} \mathrm{O}(40: 60)$ containing $250 \mathrm{mM} \mathrm{NaClO}_{4}$ as mobile phase with the flow rate $1.0 \mathrm{ml} / \mathrm{min}$ (using an RI detector)) to afford $\mathbf{1}(9 \mathrm{mg})$ and $\mathbf{3}(5 \mathrm{mg})$.

2,6-Dimethylheptyl Sulfate (1) The spectral data $\left({ }^{1} \mathrm{H}-,{ }^{13} \mathrm{C}-\mathrm{NMR}\right.$ and $\mathrm{MS}$ ) were in excellent agreement with those previously reported. ${ }^{3,4)}$

2,6-Dimethylheptyl $(R)-\alpha$-Methoxy- $\alpha$-(trifluoromethyl)phenylacetate (5) $1(2.7 \mathrm{mg})$ was dissolved in a $3 \mathrm{M} \mathrm{HCl}$ solution $(0.5 \mathrm{ml})$ and the solution was heated at $100{ }^{\circ} \mathrm{C}$ for $5 \mathrm{~h}$. Dichloromethane $\left(\mathrm{CH}_{2} \mathrm{Cl}_{2}\right)$ and water were added to the solution. The organic phase was dried over $\mathrm{Na}_{2} \mathrm{SO}_{4}$ and evaporated in vacuo to give alcohol (2). This alcohol was dissolved in pyridine- $d_{5}$ $(100 \mu \mathrm{l})$ and to the solution was added (+)-(S)-MTPA-Cl $(15 \mu \mathrm{l})$. The mixture was allowed to stand at room temperature for $30 \mathrm{~min}$, diluted with pyridine- $d_{5}(400 \mu \mathrm{l})$, and the ${ }^{1} \mathrm{H}-\mathrm{NMR}$ spectrum was recorded. The spectrum showed complete formation of the $(R)$-MTPA ester (5) without the starting alcohol. ${ }^{1} \mathrm{H}-\mathrm{NMR}\left(\mathrm{C}_{5} \mathrm{D}_{5} \mathrm{~N}\right) \delta$ : (The phenyl protons were obscured by the solvent signals.) $4.33(1 \mathrm{H}, \mathrm{dd}, J=10.7,5.8 \mathrm{~Hz}$, major $\mathrm{H}-1), 4.26(1 \mathrm{H}$, dd, $J=10.7,6.1 \mathrm{~Hz}$, minor $\mathrm{H}-1), 4.23(1 \mathrm{H}, \mathrm{dd}, J=10.7,5.9 \mathrm{~Hz}$, minor $\mathrm{H}-1), 4.16$ $(1 \mathrm{H}$, dd, $J=10.7,6.6 \mathrm{~Hz}$, major H-1), 1.77 (1H, octet, $J=6.8 \mathrm{~Hz}, \mathrm{H}-2), 1.42$ $(1 \mathrm{H}$, nonet, $J=6.6 \mathrm{~Hz}, \mathrm{H}-6), 1.35-0.98(6 \mathrm{H}, \mathrm{m}, \mathrm{H}-3,4,5), 0.86(3 \mathrm{H}, \mathrm{d}$, $J=6.6 \mathrm{~Hz}, \mathrm{Me}-2), 0.81(6 \mathrm{H}, \mathrm{d}, J=6.6 \mathrm{~Hz}, \mathrm{H}-7, \mathrm{Me}-6)$.

2,6-Dimethylheptan-1-ol (rac-2) To $255 \mathrm{mg}(1.8 \mathrm{mmol})$ of 2,6-dimethyl-5-hepten-1-al (6: commercially available) in $\mathrm{MeOH}(5 \mathrm{ml})$ was added Pd-C catalyst $(24 \mathrm{mg}, 10 \% \mathrm{w} / \mathrm{w})$. The reaction mixture was stirred at room temperature for $2 \mathrm{~h}$ under hydrogen atmosphere. The mixture was filtered and the aldehyde $(265 \mathrm{mg}, 1.8 \mathrm{mmol})$ was obtained after concentration. To a solution of $265 \mathrm{mg}(1.8 \mathrm{mmol})$ of the aldehyde in THF $(6 \mathrm{ml})$ was added $212 \mathrm{mg}(5.5 \mathrm{mmol})$ of $\mathrm{LiAlH}_{4}$. After $1 \mathrm{~h}$, the reaction was quenched by adding $200 \mu \mathrm{l}$ of $\mathrm{H}_{2} \mathrm{O}, 15 \% \mathrm{NaOH}$, and then $500 \mu \mathrm{l}$ of $\mathrm{H}_{2} \mathrm{O}$. The mixture was diluted with $10 \mathrm{ml}$ EtOAc and filtered through Celite. The filtrate was concentrated under reduced pressure to furnish $265 \mathrm{mg}(1.8 \mathrm{mmol}$, 99\% yield) of the racemic alcohol $(r a c-2) .{ }^{1} \mathrm{H}-\mathrm{NMR}\left(\mathrm{CDCl}_{3}\right) \delta: 3.45(1 \mathrm{H}$, dd, $J=10.4,5.9 \mathrm{~Hz}, \mathrm{H}-1), 3.35$ (1H, dd, $J=10.4,6.7 \mathrm{~Hz}, \mathrm{H}-1), 1.57(1 \mathrm{H}, \mathrm{m}, \mathrm{H}-$ 2), $1.49(1 \mathrm{H}$, nonet, $J=6.6 \mathrm{~Hz}, \mathrm{H}-6), 0.97-1.38(6 \mathrm{H}, \mathrm{m}, \mathrm{H}-3,4,5), 0.87$ $(3 \mathrm{H}, \mathrm{d}, J=6.6 \mathrm{~Hz}, \mathrm{Me}-2), 0.83(6 \mathrm{H}, \mathrm{d}, J=6.6 \mathrm{~Hz}, \mathrm{H}-7, \mathrm{Me}-6) .{ }^{13} \mathrm{C}-\mathrm{NMR}$ $\left(\mathrm{CDCl}_{3}\right) \delta$ : $68.2(\mathrm{C}-1), 39.2(\mathrm{C}-5), 35.7(\mathrm{C}-2), 33.4(\mathrm{C}-3), 27.9(\mathrm{C}-6), 24.7$ (C-4), 22.7 and 22.6 (C-7, Me-6), $16.6(\mathrm{Me}-2)$.

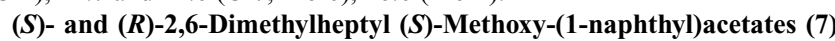
and (8) To a $\mathrm{CH}_{2} \mathrm{Cl}_{2}$ solution $(5 \mathrm{ml})$ of $\mathrm{rac}-2(116 \mathrm{mg}, 0.81 \mathrm{mmol})$ were added 1-ethyl-3-(3-dimethylaminopropyl)-carbodiimide hydrochloride (EDC) (470 mg, $2.4 \mathrm{mmol})$, 4-dimethylaminopyridine (DMAP) (300 mg, $2.4 \mathrm{mmol}), \mathrm{NEt}_{3}(510 \mu \mathrm{l}, 3.6 \mathrm{mmol})$ and $(S)$-methoxy-(1-naphthyl)acetic acid (1NMA) (261 mg, $1.2 \mathrm{mmol})$. After the mixture was stirred for $12 \mathrm{~h}, 10 \mathrm{ml}$ of $\mathrm{CH}_{2} \mathrm{Cl}_{2}$ was added, and the organic layer was washed with $10 \%$ aqueous citric acid, $5 \%$ sodium hydrogen carbonate, $\mathrm{H}_{2} \mathrm{O}$ and brine, dried over $\mathrm{Na}_{2} \mathrm{SO}_{4}$, and concentrated in vacuo to yield a crude ester. The crude ester was purified by $\mathrm{SiO}_{2}$ column chromatography with hexane/EtOAc solvent system to afford the $(S)$-1NMA ester $(261 \mathrm{mg}, 0.76 \mathrm{mmol}, 94 \%)$. The diastereomeric $(S)$-1NMA ester $(261 \mathrm{mg}, 0.76 \mathrm{mmol})$ was separated by 11 times recycling HPLC with $80 \%$ aqueous methanol on CAPCELLPAK $\mathrm{C}_{18}$ to yield the first-eluting ester (7) $(100 \mathrm{mg}, 0.29 \mathrm{mmol})$ and the second-eluting ester (8) $(90 \mathrm{mg}, 0.26 \mathrm{mmol}) .7:{ }^{1} \mathrm{H}-\mathrm{NMR}\left(\mathrm{CDCl}_{3}\right) \delta: 8.29(1 \mathrm{H}, \mathrm{d}$, $\left.J^{\prime} 8.3 \mathrm{~Hz}\right), 7.84(2 \mathrm{H}, \mathrm{t}, J=8.8 \mathrm{~Hz}), 7.61(1 \mathrm{H}, \mathrm{d}, J=6.8 \mathrm{~Hz}), 7.49(3 \mathrm{H}, \mathrm{m})$, $5.39(1 \mathrm{H}, \mathrm{s}), 3.94(1 \mathrm{H}, \mathrm{dd}, J=10.5,6.6 \mathrm{~Hz}, \mathrm{H}-1), 3.89(1 \mathrm{H}, \mathrm{dd}, J=10.5$, $5.8 \mathrm{~Hz}, \mathrm{H}-1), 3.45(3 \mathrm{H}, \mathrm{s}), 1.58(1 \mathrm{H}$, octet, $J=6.6 \mathrm{~Hz}), 1.36(1 \mathrm{H}$, nonet, $J=6.4 \mathrm{~Hz}), 1.14-0.82(6 \mathrm{H}, \mathrm{m}), 0.79(6 \mathrm{H}, \mathrm{d}, J=6.6 \mathrm{~Hz}), 0.67(3 \mathrm{H}, \mathrm{d}$, $J=6.8 \mathrm{~Hz}) .{ }^{13} \mathrm{C}-\mathrm{NMR}\left(\mathrm{CDCl}_{3}\right) \delta: 170.8,133.8,132.3,131.1,129.3,128.6$, $126.6,126.4,125.7,125.1,124.0,81.1,69.9,57.4,38.9,33.1,32.5,27.8$, 24.4, 22.6, 22.6, 16.6. 8: ${ }^{1} \mathrm{H}-\mathrm{NMR}\left(\mathrm{CDCl}_{3}\right) \delta: 8.29(1 \mathrm{H}, \mathrm{d}, J=8.6 \mathrm{~Hz}), 7.84$ $(2 \mathrm{H}, \mathrm{t}, J=8.6 \mathrm{~Hz}), 7.62(1 \mathrm{H}, \mathrm{d}, J=7.1 \mathrm{~Hz}), 7.49(3 \mathrm{H}, \mathrm{m}), 5.39(1 \mathrm{H}, \mathrm{s}), 3.96$ (1H, dd, $J=10.5,6.3 \mathrm{~Hz}, \mathrm{H}-1), 3.87(1 \mathrm{H}, \mathrm{dd}, J=10.5,6.6 \mathrm{~Hz}, \mathrm{H}-1), 3.46$ $(3 \mathrm{H}, \mathrm{s}), 1.60(1 \mathrm{H}$, octet, $J=6.4 \mathrm{~Hz}), 1.39(1 \mathrm{H}$, nonet, $J=6.6 \mathrm{~Hz}), 1.13-0.85$ $(6 \mathrm{H}, \mathrm{m}), 0.80(6 \mathrm{H}, \mathrm{d}, J=6.6 \mathrm{~Hz}), 0.65(3 \mathrm{H}, \mathrm{d}, J=6.6 \mathrm{~Hz}) .{ }^{13} \mathrm{C}-\mathrm{NMR}\left(\mathrm{CDCl}_{3}\right)$ $\delta: 170.8,133.8,132.2,131.0,129.3,128.6,126.5,126.3,125.7,125.1$, $124.0,81.0,69.9,57.4,39.0,33.2,32.4,27.8,24.3,22.6,22.6,16.5$.
Hydrolysis of $(S)$ - and $(R)-2,6-D i m e t h y l h e p t y l(S)-M e t h o x y-(1-n a p h-$ thyl)acetate The first-eluting ester (7) $(100 \mathrm{mg}, 0.29 \mathrm{mmol})$ was dissolved in a dioxane-conc. $\mathrm{HCl}$ mixture $3: 1(1.5 \mathrm{ml})$ and the mixture was heated at $110^{\circ} \mathrm{C}$ for $3 \mathrm{~h}$. Water was added to the cooled solution before extraction with hexane. The organic layer was washed with $5 \%$ sodium hydrogen carbonate and $\mathrm{H}_{2} \mathrm{O}$, dried over $\mathrm{Na}_{2} \mathrm{SO}_{4}$, and concentrated in vacuo to yield $(S)$ 2,6-dimethylheptan-1-ol $(2(S)-2)(40 \mathrm{mg}, 0.27 \mathrm{mmol}, 95 \%)$. Hydrolysis of the second-eluting ester (8) $(90 \mathrm{mg}, 0.26 \mathrm{mmol})$ was performed under the same condition, affording (R)-2,6-dimethylheptan-1-ol (2(R)-2) (35 mg, $0.24 \mathrm{mmol}, 92 \%$ ).

(S)-2,6-Dimethylheptyl $(R)-\alpha$-Methoxy- $\alpha$-(trifluoromethyl)phenylacetate (9) To a pyridine- $d_{5}$ solution $(100 \mu \mathrm{l})$ of $2(S)-2(1 \mathrm{mg})$ was added $(+)-(S)$-MTPACl $(15 \mu \mathrm{l})$ and the mixture was allowed to stand at room temperature for $30 \mathrm{~min}$, the solution diluted with pyridine- $d_{5}(400 \mu \mathrm{l})$, and the ${ }^{1} \mathrm{H}-\mathrm{NMR}$ spectrum was recorded. The ${ }^{1} \mathrm{H}-\mathrm{NMR}$ spectrum indicated complete formation of the (R)-MTPA ester (9). ${ }^{1} \mathrm{H}-\mathrm{NMR}\left(\mathrm{C}_{5} \mathrm{D}_{5} \mathrm{~N}\right) \quad \delta$ : (The phenyl protons were obscured by the solvent signals. $4.26(1 \mathrm{H}, \mathrm{dd}, J=10.7$, $6.1 \mathrm{~Hz}, \mathrm{H}-1), 4.23(1 \mathrm{H}$, dd, $J=10.7,5.9 \mathrm{~Hz}, \mathrm{H}-1), 1.77$ (1H, octet, $J=6.8 \mathrm{~Hz}$, $\mathrm{H}-2), 1.41$ ( $1 \mathrm{H}$, nonet, $J=6.8 \mathrm{~Hz}, \mathrm{H}-6), 1.34-0.97$ (6H, m, H-3, 4, 5), 0.87 $(3 \mathrm{H}, \mathrm{d}, J=6.8 \mathrm{~Hz}, \mathrm{Me}-2), 0.81(6 \mathrm{H}, \mathrm{d}, J=6.6 \mathrm{~Hz}, \mathrm{H}-7, \mathrm{Me}-6)$.

(R)-2,6-Dimethylheptyl (R)- $\alpha$-Methoxy- $\alpha$-(trifluoromethyl)phenylacetate (10) To a pyridine- $d_{5}$ solution $(100 \mu \mathrm{l})$ of $2(R)-2(1 \mathrm{mg})$ was added $(+)-(S)$-MTPA-Cl $(15 \mu \mathrm{l})$ at room temperature for $30 \mathrm{~min}$, the solution diluted with pyridine- $d_{5}(400 \mu \mathrm{l})$, and the ${ }^{1} \mathrm{H}-\mathrm{NMR}$ spectrum was recorded for the $(R)$-MPTA ester $(\mathbf{1 0})$. ${ }^{1} \mathrm{H}-\mathrm{NMR}\left(\mathrm{C}_{5} \mathrm{D}_{5} \mathrm{~N}\right) \delta$ : (the phenyl protons were obscured by the solvent signals) $4.33(1 \mathrm{H}, \mathrm{dd}, J=10.7,5.8 \mathrm{~Hz}, \mathrm{H}-1), 4.16(1 \mathrm{H}$, dd, $J=10.7,6.6 \mathrm{~Hz}, \mathrm{H}-1), 1.77(1 \mathrm{H}$, octet, $J=6.8 \mathrm{~Hz}, \mathrm{H}-2), 1.41(1 \mathrm{H}$, nonet, $J=7.1 \mathrm{~Hz}, \mathrm{H}-6), 1.35-0.98(6 \mathrm{H}, \mathrm{m}, \mathrm{H}-3,4,5), 0.86(3 \mathrm{H}, \mathrm{d}, J=6.8 \mathrm{~Hz}, \mathrm{Me}-$ 2), $0.81(6 \mathrm{H}, \mathrm{d}, J=6.6 \mathrm{~Hz}, \mathrm{H}-7, \mathrm{Me}-6)$.

$(\boldsymbol{S})$-2,6-Dimethylheptyl Sulfate (2(S)-1) The alcohol 2(S)-2 (36 mg, $0.25 \mathrm{mmol}$ ), obtained by hydrolysis of the 1NMA ester (7) was converted to the sulfate by treatment with pyridine- $\mathrm{SO}_{3}$ complex $(159 \mathrm{mg}, 1.00 \mathrm{mmol})$ in tetrahydrofuran $(3 \mathrm{ml})$ at room temperature for $24 \mathrm{~h}$. The resulting mixture was neutralized with $1 \mathrm{~m}$ sodium hydroxide solution and the aqueous solution was extracted with hexane to remove the residual alcohol. The aqueous layer was passed through an ODS column. Mineral salt was removed by washing the column with distilled water and elution with methanol gave 2(S)-1 (58 mg, $0.25 \mathrm{mmol})$. The ${ }^{1} \mathrm{H}$ - and ${ }^{13} \mathrm{C}-\mathrm{NMR}$ spectra of this product were identical with those of natural 1. HR-FAB-MS m/z: 223.1004 (Calcd for $\left.\mathrm{C}_{9} \mathrm{H}_{19} \mathrm{O}_{4} \mathrm{~S}: 223.1004\right)$. $[\alpha]_{\mathrm{D}}^{25}+2.6^{\circ}(c=0.9, \mathrm{MeOH})$.

(R)-2,6-Dimethylheptyl Sulfate (2(R)-1) The sulfate $(2(R)-1)$ was obtained in the same manner as described for $(2(S)-1)$. HR-FAB-MS $m / z$ : 223.0978 (Calcd for $\left.\mathrm{C}_{9} \mathrm{H}_{19} \mathrm{O}_{4} \mathrm{~S}: 223.1004\right)$. $[\alpha]_{\mathrm{D}}^{25}-0.9^{\circ}(c=1.0, \mathrm{MeOH})$.

(S)-6-Methyloctyl Sulfate (3) Negative HR-FAB-MS: $m / z: 223.0975$ (Calcd for $\mathrm{C}_{9} \mathrm{H}_{19} \mathrm{O}_{4} \mathrm{~S}:$ 223.1004). ${ }^{1} \mathrm{H}-\mathrm{NMR}\left(\mathrm{CD}_{3} \mathrm{OD}\right) \delta: 4.03(2 \mathrm{H}, \mathrm{t}$, $J=6.6 \mathrm{~Hz}, \mathrm{H}-1), 1.70(2 \mathrm{H}$, quint, $J=6.6 \mathrm{~Hz}, \mathrm{H}-2), 1.48-1.29(7 \mathrm{H}, \mathrm{m}, \mathrm{H}-3$, 4, 5a, 6, 7a), $1.24-1.13(2 \mathrm{H}, \mathrm{m}, \mathrm{H}-5 \mathrm{~b}, 7 \mathrm{~b}), 0.92(3 \mathrm{H}, \mathrm{t}, J=7.8 \mathrm{~Hz}, \mathrm{H}-8)$, $0.91(3 \mathrm{H}, \mathrm{d}, J=7.4 \mathrm{~Hz}, \mathrm{Me}-6) .{ }^{13} \mathrm{C}-\mathrm{NMR}\left(\mathrm{CD}_{3} \mathrm{OD}\right) \delta: 61.9(\mathrm{C}-1), 37.7(\mathrm{C}-$ 5), 35.6 (C-6), 30.6 (C-7), 30.5 (C-2), 27.8 (C-4), 27.2 (C-3), 19.6 (C-9), $11.7(\mathrm{C}-8) .[\alpha]_{\mathrm{D}}^{25}-1.9^{\circ}(c=0.15, \mathrm{MeOH})$.

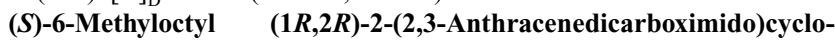
hexanecarboxylate (11) Sulfate $3(1.8 \mathrm{mg}, 7.5 \mu \mathrm{mol})$ was dissolved in $3 \mathrm{M}$ $\mathrm{HCl}(0.5 \mathrm{ml})$ and the solution was heated at $100^{\circ} \mathrm{C}$ for $5 \mathrm{~h}$. Dichloromethane and water were added to the solution. The organic phase was dried over $\mathrm{Na}_{2} \mathrm{SO}_{4}$, and evaporated in vacuo to give the alcohol (4). To a $\mathrm{CH}_{2} \mathrm{Cl}_{2}$ solution of the alcohol (4), were added EDC ( $1 \mathrm{mg}, 5.2 \mu \mathrm{mol})$, DMAP $(0.6 \mathrm{mg}$, $4.9 \mu \mathrm{mol}), \mathrm{NEt}_{3}(1 \mu \mathrm{l}, 6.3 \mu \mathrm{mol})$ and $(1 R, 2 R)-2-(2,3$-anthracenedicarboximido)cyclohexanecarboxylic acid $(0.6 \mathrm{mg}, 1.5 \mu \mathrm{mol})$. After the mixture was stirred for $16 \mathrm{~h}$ at room temperature, the crude ester was purified by $\mathrm{SiO}_{2}$ column chromatography with hexane/EtOAc solvent system to afford the ester 11.

Acknowledgments We are grateful to Dr. K. Akasaka and Prof. H. Ohrui of the Graduate School of Life Sciences, Tohoku University for providing us Ohrui reagents.

\section{References}

1) Hessen D. O., van Donk E., Hydrobiologia, 127, 129-140 (1993).

2) Yasumoto K., Nishigami A., Yasumoto M., Kasai F., Okada Y., Kusumi T., Ooi T., Tetrahedron Lett., 46, 4765-4767 (2005).

3) Tsukamoto S., Kato H., Hirota H., Fusetani N., J. Nat. Prod., 57, 1606-1609 (1994).

4) Crispino A., De Giulio A., De Rosa S., De Stefano S., Milone A., J. Nat. Prod., 57, 1575-1577 (1994). 
5) Salvatore D. R., Alfredo M., Antonio C., Andrej J., Alfonso D. G., J. Nat. Prod., 60, 462-463 (1997).

6) Tsuda M., Toriyabe Y., Endo T., Kobayashi J., Chem. Pharm. Bull., 51, $448-451$ (2003).

7) Huo S., Negishi E., Org. Lett., 3, 3253-3256 (2001).

8) Kusumi T., Takahashi H., Ping X., Fukushima T., Asakawa Y.,
Hashimoto T., Kan Y., Tetrahedron Lett., 35, 4397-4400 (1994).

9) Kusumi T., Takahashi H., Hashimoto T., Kan Y., Asakawa Y., Chem. Lett., 6, 1093-1094 (1994).

10) Imaizumi K., Terasima H., Akasaka K., Ohrui H., Anal. Sci., 19, $1243-1249$ (2003). 